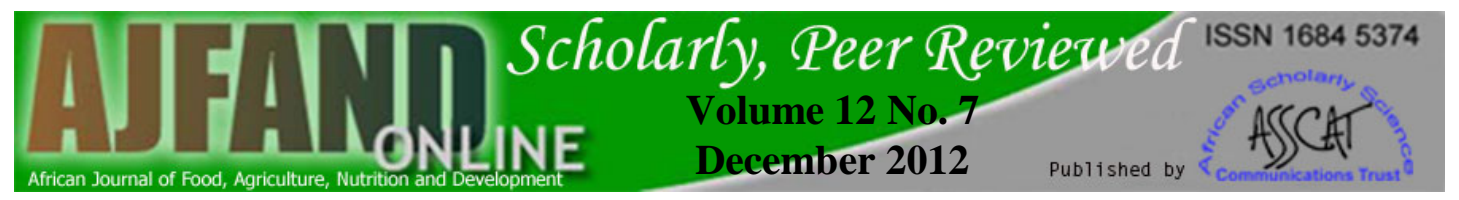

\title{
USE OF IMPROVED INPUTS AND ITS EFFECT ON MAIZE YIELD AND PROFIT IN UGANDA
}

\section{Okoboi $\mathrm{G}^{1^{*}}$, Muwanga $\mathrm{J}^{2}$ and $\mathrm{T}$ Mwebaze ${ }^{2}$}

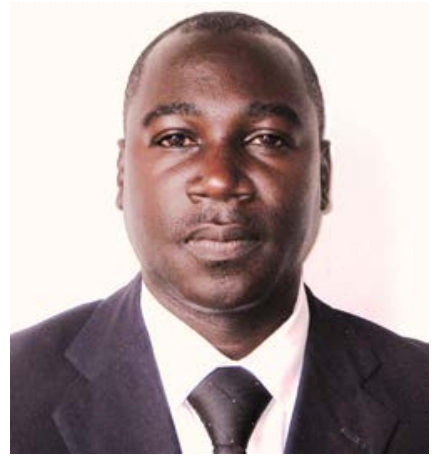

Geofrey Okoboi

*Corresponding author e-mail: okoboi@eprc.or.ug

${ }^{1}$ Economic Policy Research Centre, Plot 51 Pool Road, Makerere University, P.O. Box 7841, Kampala, Uganda.

${ }^{2}$ College of Business and Management Science, Makerere University, P.O. Box 7062, Kampala, Uganda 


\section{ABSTRACT}

Maize is an important crop, produced by nearly all households in Uganda. Yet, the yield of the crop is low, mainly blamed on low use of improved technologies. In a bid to understand why farmers are reluctant to adopt modern agricultural technologies, which are hailed for enhancing productivity, this study assessed the effect of improved inputs use on maize yield and profit in Uganda. The analysis was based on the Uganda National Household Survey data of 2005/06. A graphical analysis was used to assess the yield and profit outcomes associated with use of improved seed and fertiliser. Stochastic production functions of yield and profit were estimated to assess the effect of use of improved inputs on yield and profit. Graphical results indicated that maize producers who applied fertiliser on improved seed obtained the highest yield but lower gross profit margin while farmers who never applied fertiliser on improved seed obtained lower yield but the highest gross profit margin. Regression results indicated that higher expenditure on fertiliser and traction per hectare had a significant $(\mathrm{p}<0.05)$ positive effect on yield. No significant effect on gross profit margin was however observed in the case of higher expenditure on fertiliser and traction per hectare in maize production. Results indicate that whereas expansion in area cultivated had a significantly $(\mathrm{p}<0.01)$ negative effect on yield, it was the most important $(\mathrm{p}<0.01)$ means of increasing profit. Education level and access to extension services are key farmer characteristics that were found to have a significantly $(p<0.01)$ positive influence on the profit and yet no remarkable influence on yield. Notable was that maize producers that were members in the government extension agency, National Agricultural Advisory Services organization, (NAADS) had lower yield than farmers not in NAADS. These results suggest that NAADS and other agencies that are involved in promoting use of modern agricultural technologies in Uganda have an uphill task of proving and hence persuading farmers that use of these technologies not only enhances yield but also increases farm profits.

Key words: Improved inputs, yield, profit, maize 


\section{INTRODUCTION}

Maize is an important crop in Uganda, cultivated by about 86 percent of the 4.2 million agricultural households in the country [1]. The crop is a staple for the urban poor, and in institutions such as schools, hospitals and the military. Also, maize is the main source of income for most farmers in Eastern, Northern and north-Western Uganda, who sell it either as grain or when processed into local brew [2]. At national level, maize ranks number-one in terms of food-crop export revenue [3]. Besides, maize has a wide range of other potential processed products, including cooking oil, ethanol, starch and sucrose; though this component of the value-chain is not yet exploited in Uganda.

Due to the present and potential uses of maize, the crop is ranked top on the list of strategic food security crops in Uganda [5]. Maize is the only cereal crop among the ten priority crops identified by government for a multi-million shilling five-year targeted intervention as proposed in the new Development Strategy and Investment Plan (DSIP) 2010/11 - 2014/15 of the Ministry of Agriculture Animal Industry and Fisheries (MAAIF) [5].

Despite the importance of maize in Uganda, FAO data indicates that crop output is only 1.3 million tonnes (or 0.4 t per agricultural household) and the yield is stagnant at a low level of 1.5 tonnes (t) per hectare (ha) (t/ha) (6) compared to potential yield of $7 \mathrm{t} /$ ha [7]. Limited use of improved inputs in production such as improved seeds and fertiliser is widely regarded as the major constraint to increased output and productivity [5]. This is due to the fact that only 1, 6, and 7 per cent of agricultural parcels in Uganda are applied with chemical fertiliser, improved seed and/or manure respectively [1], compared to other countries, particularly in Asia, that are associated with a high level of improved inputs use as well as productivity [8].

Increase in per capita use of fertiliser, high yielding seed varieties and irrigation is particularly commended for the Asian green revolution [9]. However, increase in yield per se may not be sufficient to guarantee increased adoption of improved technologies, particularly by poor farmers when the cost of such inputs is likely to be relatively high compared to their income. The economic return from use of improved inputs is considered to be more critical in assessing technology adoption than yield $[10,11]$.

In a bid to understand why some farmers may be reluctant to adopt these technologies, which are hailed for enhancing productivity, this study set out to simultaneously analyse the effect of improved inputs use on yield and profit in maize production. Following this approach, the study provides evidence of the key inputs that influence the crop yield and/or profit in Uganda. Crop specific evidence is important for targeted intervention to promote technology adoption. 


\section{METHODS}

\section{The model}

To compare of effect of improved inputs use on yield and gross profit margin, a production function was estimated. Following the approach by Kumbhakar and Lovel Knox [12], a production function was specified as in equation (1):

$$
y_{i}=f\left(A_{k i}, x_{j i}, \beta\right) \cdot e^{\varepsilon_{i}} ; i=1, \ldots \ldots . . N
$$

Where $y_{i}$ is yield or gross profit margin of farmer $i$; $A_{k i}$ is the area $k$ under cultivation by farmer $i, x_{j i}$ is the amount spent on input $j$ (e.g. seed, fertiliser) by farmer $i, \beta$ is a vector of coefficients estimated, $e$ is the expression for exponential, and $\varepsilon_{i}$ is the error term, consisting of the stochastic term, $v_{\mathrm{i}}$ and the inefficiency variables, $u_{i}$. That is $\varepsilon_{i}=v_{i}-u_{i}$. The $v_{\mathrm{i}}$ 's are assumed to be normally distributed and independent of $u_{i}$ 's. While $u_{i}$ 's are non-negative random variables associated with the inefficiency in the yield/gross profit. In agricultural analysis, the inefficiency variables are farmer/farm characteristics. Farmer characteristics include variables such as sex, age, and education level, while farm characteristics include variables such as soil types and topography.

In general, equation 1 is composed of two parts; the general model $f($.$) and the$ inefficiency model $(\varepsilon)$. In the explicit form, (1) is specified as in (2).

$$
y_{i}=\beta_{0}+\beta_{1} \ln A_{j i}+\sum_{j=2}^{7} \beta_{j} \ln X_{j i}+\left[v_{j i}+\left(\gamma_{0}+\sum_{k=1}^{13} \gamma_{k} z_{k i}\right)\right]
$$

Where, In implies natural logarithm, $X_{2 i}, X_{2 i}, . ., X_{7 i}$ are variables representing amount spent by farmer $i$ on seed, fertiliser, herbicides/fungicides, traction, manure and hired labour. The $Z_{1}, Z_{2}, . ., Z_{13}$ are farmer characteristics including residence of farmer in urban or rural area, family size, sex, age, education level, access to extension services, access to credit, membership in farmer association, membership in the National Agricultural Advisory Services (NAADS) programme, value of livestock and/or poultry owned, and residence of farmer in Central, Eastern, Northern or Western Uganda.

\section{Data}

Data used in this paper are from Uganda National Household Survey (UNHS) 2005/06. The UNHS 2005/06 had five modules namely: Socio-economic, Agriculture, Community, Price and Qualitative modules. For this study however, data were derived from the Socio-economic and Agriculture modules of the survey. The survey was conducted by the Uganda Bureau of Statistics (UBoS) in all the districts in Uganda as of 2005 [1]. From the Agriculture module, data on maize production such as maize output, factor inputs use and cost, access to extension services and credit, were generated and matched with data on farmer characteristics that were derived from the Socio-economic module. 
Data for the dependent and explanatory variables to fit the model, which were derived from the UNHS 2005/06 are presented in Table 1. The second column in Table 1 defines the variables while the last two columns give the mean and standard error. The mean value statistics indicate for example that in 2005/06, average maize yield in Uganda was 1.94 tonnes per hectare while farmer expenditure on fertiliser per hectare cultivated averaged Uganda shillings 594. For variables that are dichotomous, the mean values are interpreted as proportion or percent when multiplied by a hundred. For example, with regards to access to extension services and credit, 16.4 and 3.4 percent of the farmers had access to extension services and credit, respectively.

\section{Model estimation}

To estimate the parameters $(\beta, v, \gamma)$ in (2), the data for continuous variables: yield, seed, fertiliser, herbicides/fungicides, traction, manure and hired labour except gross profit margin were transformed into natural logarithms to normalise data as well ease the interpretation of the estimated coefficients as elasticities [12]. The gross profit margin variable was not transformed into natural logarithm as some observations were negative. Elasticities of continuous variables of the profit function were however obtained as in (3)

(3) $e_{i}=\frac{\partial \pi_{i}}{\partial \ln x_{i}} \cdot \frac{1}{\bar{\pi}}$

Where $\frac{\partial \pi_{i}}{\partial \ln x_{i}}$ is the coefficient $i^{\text {th }}$ continuous variable, and $\bar{\pi}=0.88$ (mean gross profit margin).

Estimation of equation 2 was carried out in one-step using the Frontier model's maximum likelihood technique in STATA software, version 11. For interpretation, positive values of the parameters $\gamma$, imply negative effect of the variable on yield or gross profit margin while negative values imply positive effect of the variable on yield or gross profit margin.

\section{RESULTS}

\section{Yield and gross profit comparison by seeds type and fertiliser use}

Figure 1 presents the yield and gross profit margin arising from use or non-use of fertiliser on different types of maize seed. The graph indicates that farmers who applied fertiliser on market-sourced improved (MSI) seed (considered best quality seed, in this paper) obtained the highest average yield (about $3.5 \mathrm{t} / \mathrm{ha}$ ) but lower gross profit margin (about UGX 380,000/ha) compared for example to the yield ( $2.5 \mathrm{t} / \mathrm{ha}$ ) and gross profit margin (UGX 460,000/ha) for farmers who planted home-saved improved (HSI) seed (which is of lower quality than MSI seed). Even farmers who planted MSI seed without fertiliser obtained higher gross profit margin (UGX 400,000/ha) though lower yield (2.6 t/ha) compared to farmers who applied fertiliser on MSI seed. 


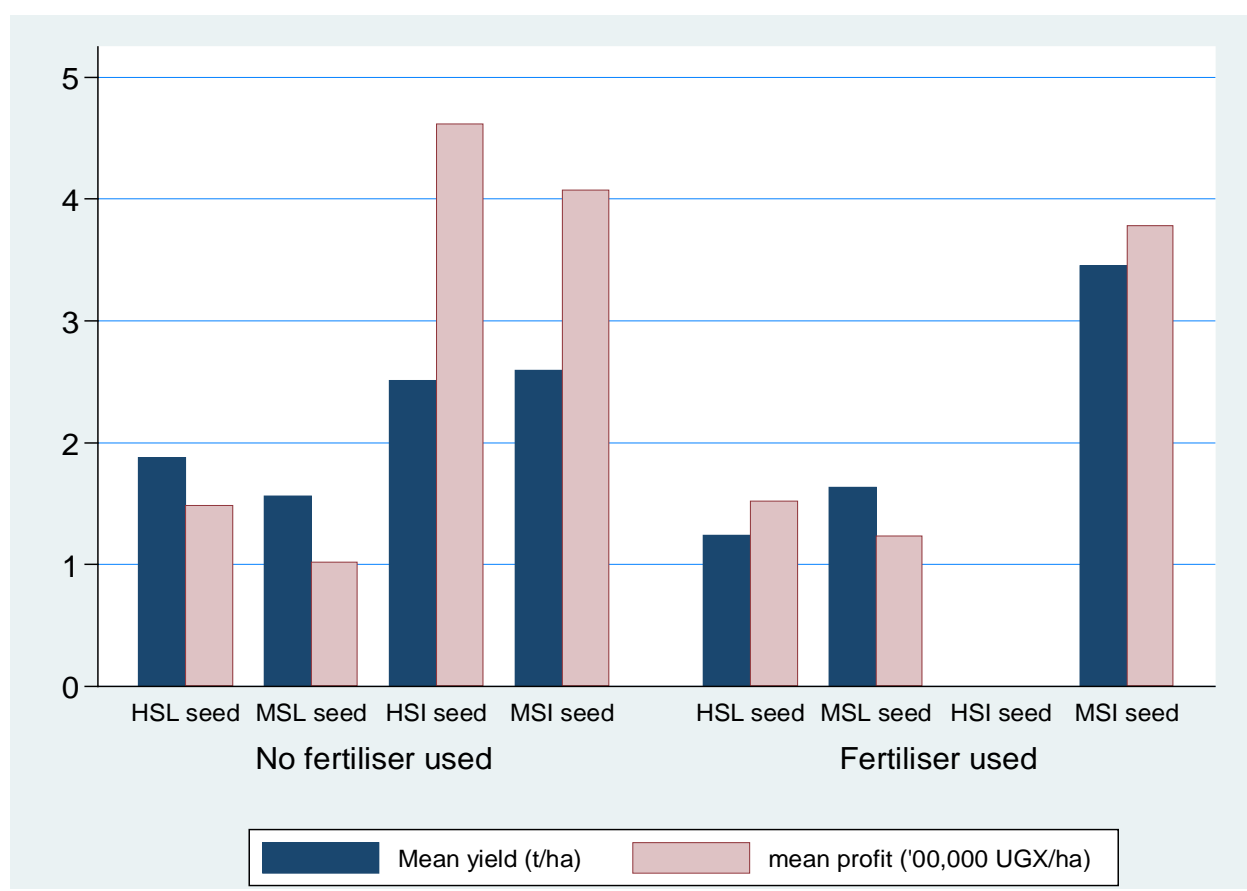

Figure 1: Yield and gross profit margin by seeds type with and without fertiliser use

Perhaps more revealing from Figure 1 is that use of fertilizer on low quality seed such as home-save local (HSL) seed or market-sourced local (MSL) seed is a waste of resources, as both yield and gross profit margin for farmers who used fertiliser on this type of seed was not only low but rather similar or lower in some instances, compared to yield and gross profit margin for farmers who did not use fertiliser on similar seed.

\section{Costs and returns in maize production}

Table 2 shows the farmers' average expenditure on improved inputs, hired labour as well as the opportunity cost of farmers' own inputs (family labour and land). The total variable cost (TVC) is the sum of all monetary costs while the net profit is the gross profit less imputed cost of own inputs. Overall, results reveal that farmers spent more on hire of labour than on purchase of improved inputs. In particular, farmers in Western Uganda spent on average three times more on hiring labour (UGX 0.051 million) compared to expenditure on improved inputs (UGX 0.017 million), while in Central region farmers spent twice more on labour hire than on improved inputs.

Also, Table 2 shows that when the opportunity cost of family labour and land is imputed into maize production costs, the net profit is negative. Although farmers in Western Uganda got the highest gross profit, the net profit loss is highest (UGX -0.15 million) due to the high imputed value to their own land and labour involved in production. Farmers in Central region had the second highest net profit loss (UGX 0.12 million) also due to the high imputed value of own land and labour involved in production. 
Figure 2 shows the trend of costs and profit as area under maize production increases. The graph indicates that farmers' gross profit significantly increases with increase in area cultivated (suggesting economies of scale) up to about three hectares and thereafter declines, probably due to diseconomies of scale. That is, farmers cultivating an average of one hectare made an average gross profit of UGX 0.5 million/ha while those cultivating an average of three hectares made an average gross profit of at least UGX 1.5 million/ha.

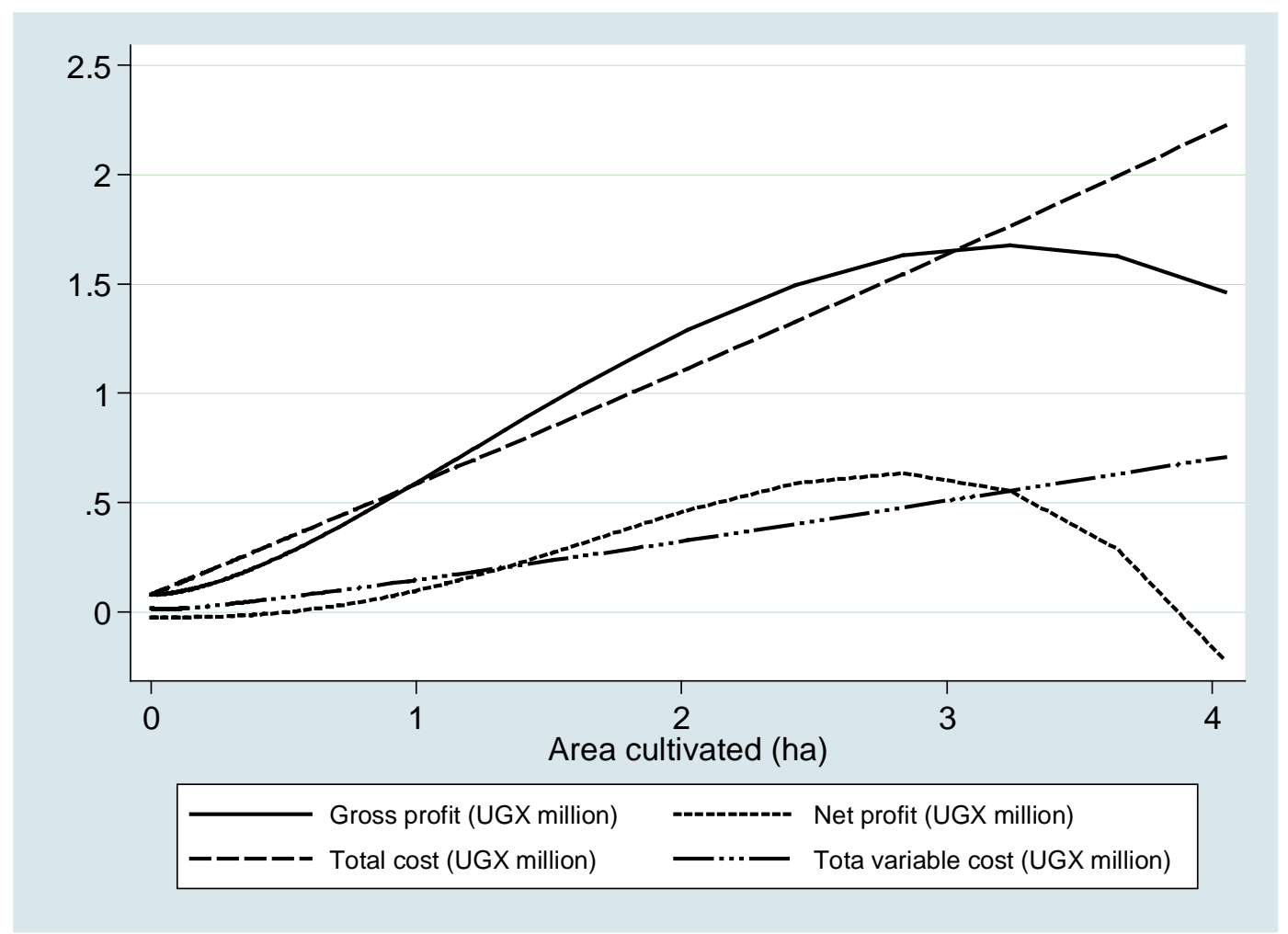

Figure 2: Estimated costs and returns based on area cultivated

With imputation of the opportunity cost of land and labour in production costs, however, the graph indicates that farmers' net profit increases moderately reaching UGX $0.5 \mathrm{million} / \mathrm{ha}$ at 3 hectares and thereafter declines rapidly to negative net profit at 4 hectares. Furthermore, the graph indicates that whereas farmers cultivating 4 or more hectares of maize are likely to get high gross profit margin (UGX 1.5 million/ha), net profit is negative due to higher opportunity cost family labour and own land compared to the marginal revenue.

\section{Econometric results}

Results of maximum likelihood estimate of equation 2 for yield and gross profit functions are presented in Table 3. In the gross profit model, factor inputs and gross profit data were normalised by dividing each one of them by maize grain price. Wald chi-square statistics of all the models were statistically significant $(p<0.01)$, suggesting robust estimates. 
The coefficients for improved inputs (seed, fertilizer, herbicides/fungicides and traction) in both the yield and gross profit models were all positive, though none of the coefficients in the profit model were statistically significant and only the coefficients for fertilizer and traction in the yield model were statistically significant at 5 per cent level. This result supports the descriptive statistics in Figure 1, which indicated that farmers using improved inputs such as fertiliser and improved seed from agro-input shops, obtained high yield but low profit.

Of all the factor inputs used in maize production, Table 3 indicates that only increase in area cultivated had a significantly $(\mathrm{p}<0.01)$ positive effect on gross profit; which corresponds with the descriptive statistics in Figure 2. Yet, in the yield model, as would be expected, results indicate the increase in area cultivated had a highly $(\mathrm{p}<0.01)$ negative effect on yield.

Although results in Table 3 indicate that the effect of manure use on maize yield was somewhat positive but not significant, instead it had a negative effect on profit, perhaps due to the cost of the input compared to marginal output associated with its application.

Results of the inefficiency model show that, farmers with larger households obtained significantly $(\mathrm{p}<0.05)$ higher yield as well as gross profit. Results indicate that although older farmers obtained significantly $(\mathrm{p}<0.01)$ lower yield, they obtained fairly $(p<0.1)$ higher profit than their younger peers. A bit surprising is that both education level and access to extension services are shown to have a positive and significant $(p<0.01)$ effect on profit but not yield. Other results to consider from the inefficiency model relate to membership in NAADS, access to credit and regional location of farmers. Results indicate that whereas farmers in other regions had significantly $(\mathrm{p}<0.01)$ lower yield compared to their counterparts in Eastern Uganda, lower yield did not translate into significantly lower gross profit. The last observation to make from the results is that although farmers who were members in NAADS as well as those who accessed agricultural credit were associated with lower yield, they did not experience significant differences in gross profit compared to farmers who were not members of NAADS or did not access agricultural credit.

\section{DISCUSSION}

Use of improved seed, fertiliser, herbicides/fungicides, and traction in maize production in Uganda is low. Both family labour and land remain the dominant inputs in maize production. Nonetheless, the opportunity cost of labour and land engaged in maize production is higher than the gross profit margin. This suggests that at the prevailing state of maize production technology and market conditions in Uganda, it would be more rewarding if opportunities exist, for farmers to hire-out labour and land than engage these resources maize production.

Although use of improved inputs such as fertiliser and traction is yield enhancing, the economic return from use of these inputs is low due to the high cost of the inputs. Given that farmers are rational in allocation of resources to enterprises that are likely

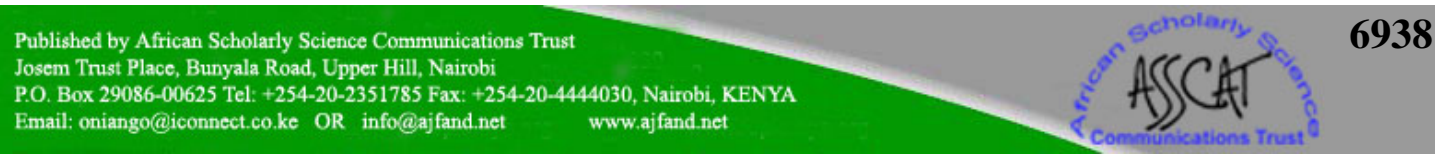


to bring higher returns is probably the most important reason why use of improved inputs in Uganda remains low, even when government through programmes such as NAADS is encouraging farmers to use these inputs.

Expansion of area cultivated, which is mainly on own land and use of household labour appears to be the most important means of minimising production costs and hence guaranteeing higher profit from maize production in Uganda. Otherwise, when farmers' own inputs (land and labour) are imputed into production costs, maize production is an economic loss-making enterprise. This suggests that without intensive use of family resources, many farmers in Uganda would abandon maize cultivation.

Farmers with a higher level of education earned higher profit from maize production even though their yield was not that different from less educated farmers. This implies that higher profit was due to producing a larger quantity and/or selling at a higher price. More educated farmers are more likely to cultivate larger parcels of land as they have a higher disposable income from wage employment and/or non-agricultural enterprises [14]. Also, more educated farmers are less likely to sell their crops at throw-away prices due to financial constraints as is common with poor farmers who usually sell their crops immediately after harvest in order to purchase essential goods or meet other crucial family needs.

Farmer access to extension services is shown elsewhere to enhance yield more than profit [15]. Results of this study suggest the opposite situation however. Farmers who access extension services get information on sources and prices of inputs, advice on proven seed varieties and fertiliser to use as well as other crop husbandry practices to adopt, and output market information [16], which are important for decision making regarding use or non-use of the inputs as well as the appropriate markets to target.

\section{CONCLUSION}

The objective of this study was to examine the effect of improved inputs use on profit as compared with yield in maize production, in order to understand why some farmers may be reluctant to adopt some production technologies that hitherto are highly recommended for enhancing productivity. Results indicate that on average, farmers who use improved inputs such as certified seed, fertiliser, fungicides and/or traction get high yield but low profit, which is in contrast to the yield and profit of farmers who do not use these inputs. Evidence suggests that maize producers in Uganda earn profits mainly through expansion of the area cultivated. This implies that agencies that are involved in promoting use of improved inputs in Uganda have an uphill task of proving and hence convincing farmers that use of modern technologies not only enhances yield but also increases farm profits. 
Table 1: Definition and summary statistics of variables used in the study

\begin{tabular}{|c|c|c|c|}
\hline Variables & Definition and/or unit of measure & Mean & Std. error \\
\hline \multicolumn{4}{|l|}{ Dependent variables } \\
\hline Yield & Tonnes per hectare & 1.942 & 0.027 \\
\hline Gross profit margin & Uganda shillings, millions per hectare of grain & 0.188 & 0.006 \\
\hline \multicolumn{4}{|l|}{ Explanatory variables } \\
\hline Seed & Expenditure (Uganda shillings) per hectare & 6660 & 258 \\
\hline Fertiliser & Expenditure (Uganda shillings) per hectare & 594 & 86 \\
\hline Fungicides/herbicides & Expenditure (Uganda shillings) per hectare & 990 & 116 \\
\hline Traction cost & Expenditure (Uganda shillings) per hectare & 6608 & 317 \\
\hline Manure & Quantity (kilograms) applied per hectare & 22.754 & 9.38 \\
\hline Area & Hectare cultivated & 0.31 & 0.01 \\
\hline Hired labour & Expenditure (Uganda shillings) per hectare & 23744 & 1105 \\
\hline Urban & $1=$ Urban resident, $0=$ rural resident & 0.07 & 0.006 \\
\hline Family size & Number of people in household & 6.43 & 0.08 \\
\hline Sex & $1=$ farmer is male, $0=$ farmer is female & 0.78 & 0.01 \\
\hline Age & Age of farmer in years & 43.03 & 0.36 \\
\hline \multirow[t]{4}{*}{ Educ. level } & $1=$ farmer without formal education & 0.168 & 0.009 \\
\hline & 2=farmer has some primary level education; & 0.58 & 0.011 \\
\hline & 3=farmer has some secondary level education; & 0.176 & 0.009 \\
\hline & 4=farmer has tertiary/specialised training & 0.076 & 0.006 \\
\hline Extension & $1=$ farmer access to extension services, $0=$ No & 0.164 & 0.009 \\
\hline Farmer Assoc. & $1=$ farmer member of farmer association, $0=$ No & 0.063 & 0.006 \\
\hline NAADS & $1=$ farmer member of NAADS organisation, $0=$ No & 0.246 & 0.011 \\
\hline Credit & $1=$ farmer access credit from financial institution, $0=$ No & 0.034 & 0.004 \\
\hline Lvstk & $\begin{array}{l}\text { Value (Uganda shillings, millions) of farmer's } \\
\text { cattle/goats/pigs/poultry }\end{array}$ & 0.501 & 0.073 \\
\hline Central & $1=$ farmer resident in Central Uganda, $0=$ No & 0.197 & 0.01 \\
\hline Eastern & $1=$ farmer resident in Eastern Uganda, $0=$ No & 0.44 & 0.012 \\
\hline Northern & $1=$ farmer resident in Northern Uganda, $0=$ No & 0.166 & 0.009 \\
\hline Western & $1=$ farmer resident in Western Uganda, $0=$ No & 0.198 & 0.011 \\
\hline \multirow[t]{4}{*}{ Seed type } & 1=Home-saved local (HSL) seed & 0.636 & 0.012 \\
\hline & 2=Market-sourced local (MSL) seed; & 0.192 & 0.009 \\
\hline & 3=Homed-saved improved (HIS) seed; & 0.069 & 0.006 \\
\hline & 4=Market-sourced improved (MSI) seed & 0.104 & 0.007 \\
\hline Fertilizer use & $1=$ farmer used , $0=$ No & 0.015 & 0.003 \\
\hline
\end{tabular}

Source: Author's calculations based on UNHS 2005/06 data 


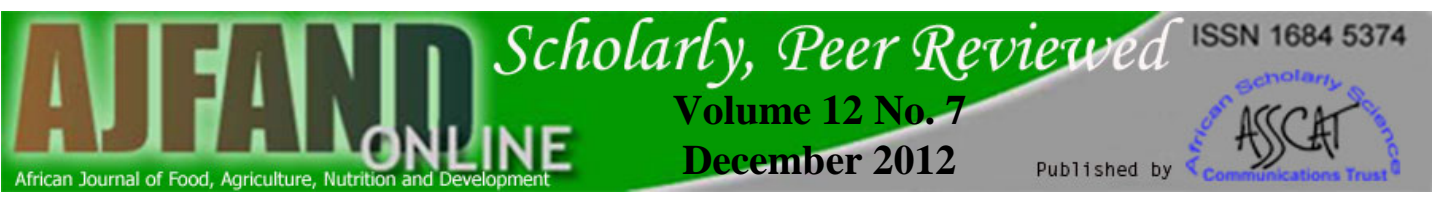

Table 2: Average expenditure and returns per hectare of maize, UGX millions

\begin{tabular}{lccccc}
\hline Expenditure item & Central & East & North & West & National \\
\hline Improved (capital) inputs & 0.014 & 0.019 & 0.013 & 0.017 & 0.017 \\
Hired labour & 0.031 & 0.017 & 0.015 & 0.051 & 0.025 \\
Total variable cost & 0.045 & 0.036 & 0.028 & 0.068 & 0.042 \\
Total revenue & 0.204 & 0.247 & 0.134 & 0.299 & 0.226 \\
Gross profit margin & 0.158 & 0.211 & 0.107 & 0.230 & 0.184 \\
$\begin{array}{l}\text { Imputed cost of family labour } \\
\text { and own land }\end{array}$ & 0.277 & 0.233 & 0.133 & 0.380 & 0.247 \\
Net profit & -0.119 & -0.022 & -0.026 & -0.149 & -0.063 \\
\hline
\end{tabular}

Source: Author's own calculations based on UHNS 2005/06 data 


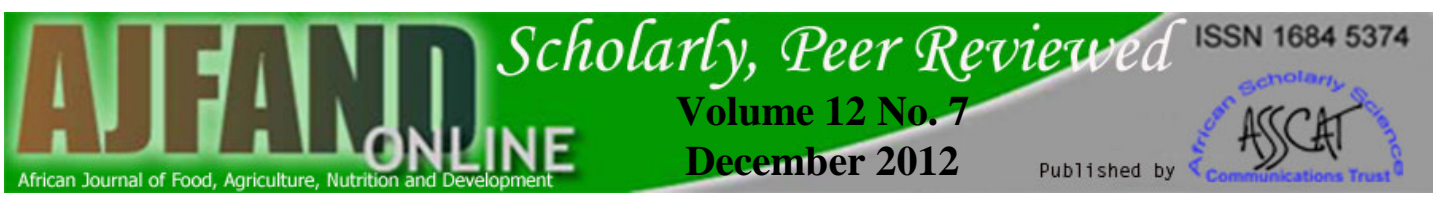

Table 3: Maximum likelihood estimates of the yield and gross profit -half normal model

\begin{tabular}{|c|c|c|c|c|}
\hline \multirow[b]{2}{*}{ Explanatory variables } & \multicolumn{2}{|c|}{ Ln(yield) } & \multicolumn{2}{|c|}{ Gross profit (normalised) } \\
\hline & Coef. & $\mathrm{z}$ & Coef. & $\mathrm{z}$ \\
\hline \multicolumn{5}{|l|}{ Factor inputs } \\
\hline Ln(seed) & 0.002 & 0.66 & 0.018 & 0.95 \\
\hline $\begin{array}{l}\text { Ln (fertiliser) } \\
\text { Ln (fungicides/ }\end{array}$ & $0.033^{* *}$ & 2.14 & 0.046 & 0.81 \\
\hline Herbicides) & $0.026^{*}$ & 1.66 & 0.017 & 0.33 \\
\hline Ln (traction) & $0.009 * *$ & 2.06 & 0.025 & 0.78 \\
\hline Ln (manure) & 0.004 & 0.13 & $-0.17^{* *}$ & -2.35 \\
\hline Ln (plotsize) & $-0.339 * * *$ & -10.74 & $0.526 * * *$ & 8.08 \\
\hline Ln(hired labour) & $0.034 * * *$ & 4.94 & 0.016 & 0.92 \\
\hline Intercept & $7.360 * * *$ & 59.29 & $0.455^{* * *}$ & 10.11 \\
\hline $\operatorname{Ln}\left(v^{2}\right)$ & $-0.381 * *$ & -2.43 & $-1.60 * * *$ & -8.03 \\
\hline \multicolumn{5}{|c|}{ Inefficiency variables $\left[\operatorname{Ln}\left(u^{2}\right)\right.$} \\
\hline Urban & 0.242 & 1.34 & 2.17 & 1.49 \\
\hline Hhsize & $-0.038 * *$ & -2.08 & $-0.17 * *$ & -2 \\
\hline Gender & -0.044 & -0.33 & $1.28 *$ & 1.92 \\
\hline Age & $0.013^{* * *}$ & 5.56 & $-0.04 *$ & -1.79 \\
\hline Educ & 0.003 & 0.66 & $-0.32 * * *$ & -5.07 \\
\hline Ext & -0.334 & -1.49 & $-39.53 * * *$ & -6.67 \\
\hline Group & -0.208 & -0.72 & 1.15 & 0.49 \\
\hline NAADS & $0.215^{* * *}$ & 2.54 & -0.29 & -0.8 \\
\hline Credit & $0.358 * *$ & 2.28 & -0.15 & -0.16 \\
\hline Ln(lvstk) & $-0.023^{* * *}$ & -2.07 & -0.07 & -1.14 \\
\hline Central & $0.301^{* * *}$ & 4.88 & 0.17 & 0.27 \\
\hline Northern & $0.575^{* * *}$ & 5.31 & 0.07 & 0.08 \\
\hline Western & $0.462 * * *$ & 5.06 & 0.11 & 1.14 \\
\hline Wald Chi square & $135.61 * * *$ & & $72.62 * * *$ & \\
\hline Log pseudo likelihood & -2095072 & & -814248 & \\
\hline
\end{tabular}

Notes: ***, ** and * imply coefficients statistically significant at 1,5 and 10 per cent respectively.

Eastern Uganda is the comparison (base-case scenario) region.

Source: Author’s calculations based on UNHS 2005/06 


\section{REFERENCES}

1. UBoS (Uganda Bureau of Statistics). Uganda National Household Survey: Agricultural Module Report. UBoS, Kampala, Uganda, 2007.

2. Ferris S, Engoru P, Wood $\mathbf{M}$ and $\mathbf{E}$ Kaganzi Evaluation of the market information services in Uganda and recommendations for the next five years. PMA /ASPS Report, Kampala, Uganda, 2006.

3. MFPED (Ministry of Finance Planning and Economic Development) Background to the Budget 2008/09 Fiscal Year: Achieving Prosperity for All through Infrastructure Development, Enhancing Employment and Economic Growth. MFPED, Kampala, Uganda, 2008.

4. SPEED (Rural Savings Promotion and Enhancement of Enterprise Development Project) Warehouse Receipt Financing: A Banking Perspective. Final Report, Kampala, Uganda, 2006.

5. MAAIF (Ministry of Agriculture Animal Industry and Fisheries) Agriculture for Food and Income Security: Agricultural Sector Development Strategy and Investment Plan 2010/11 - 2014/15. MAAIF, Entebbe, Uganda, 2010.

6. FAO. Area Cultivated and Output of Maize in Uganda. http://faostat.fao.org/site/339/default.aspx (Accessed January 2010).

7. NARO (National Agricultural Research Organisation). Technologies Released at NAARI. http://www.naro.go.ug/technologies/naaritechn.htm (Accessed January 2010).

8. Hazell PBR and MW Rosegrant Transforming the Rural Asian Economy: The Unfinished Revolution. Oxford University Press, 2000.

9. World Bank. World Development Report 2008: Agriculture for Development. Washington, DC, 2007.

10. FAO (Food and Agriculture Organization of the United Nations) Fertiliser use by crop. FAO Fertiliser and Plant Nutrition Bulletin 17, 2006. ftp://ftp.fao.org/docrep/fao/009/a0443e/a0443e00.pdf (Accessed February 2010).

11. Kelly VA Factors Affecting Demand for Fertiliser in Sub-Saharan Africa. Agriculture and Rural Development Discussion Paper 23. World Bank. 2006.

12. Kumbhakar SC and CA Lovel Knox Stochastic Frontier Analysis. Cambridge University Press, Cambridge, 2000. 
13. Bauer PW Recent Developments in the Econometric Estimation of Frontiers. Journal of Econometrics, 1990; 46:39-56.

14 UBoS Uganda National Household Survey: Socio-economic Module. Abridged Report. Kampala, Uganda: UBoS, 2010.

15. Bravo-Ureta BE and AE Pinheiro Technical, Economic, and Allocative Efficiency in Peasant Farming: Evidence from the Dominican Republic. The Developing Economies, 1997; XXXV-1:48-67.

16 Langyintuo A and M Mekuria Modeling Agricultural Technology Adoption Using the Software STATA. CIMMYT-ALP Training Manual No. 1/2005 (Part Two). International Maize and Wheat Improvement Center, Harare, 2005. 